\title{
Insulin-like growth factor II acts through an endogenous growth pathway regulated by imprinting in early mouse embryos
}

\author{
Daniel A. Rappolee, ${ }^{1}$ Karin S. Sturm, ${ }^{2}$ Ole Behrendtsen, Gilbert A. Schultz, ${ }^{3}$ Roger A. Pedersen, \\ and Zena Werb ${ }^{4}$
}

Laboratory of Radiobiology and Environmental Health, Department of Anatomy, and Program in Developmental Biology, University of California, San Francisco, California 94143-0750 USA

\begin{abstract}
We present evidence that insulin-like growth factor II (IGF-II) mediates growth in early mouse embryos and forms a pathway in which imprinted genes influence development during preimplantation stages. mRNA and protein for IGF-II were expressed in preimplantation mouse embryos, but the related factors IGF-I and insulin were not. IGF-I and insulin receptors and the IGF-II/mannose-6-phosphate receptor were expressed.

Exogenous IGF-II or IGF-I increased the cell number in cultured blastocysts, but a mutant form of IGF-II that strongly binds only the IGF-II receptor did not. Reduction of IGF-II expression by antisense IGF-II oligonucleotides decreased the rate of progression to the blastocyst stage and decreased the cell number in blastocysts. Preimplantation parthenogenetic mouse embryos expressed mRNA for the IGF-II receptor but not for either IGF-II ligand or the IGF-I receptor, indicating that the latter genes are not expressed when inherited maternally. These data imply that some growth factors and receptors, regulated by genomic imprinting, may control cell proliferation from the earliest stages of embryonic development.
\end{abstract}

[Key Words: Insulin-like growth factor; PCR; antisense oligonucleotides; insulin receptor; blastocysts; zygotic transcription; receptor tyrosine kinase; genomic imprinting]

Received August 2, 1991; revised version accepted April 9, 1992.

The mammalian embryo can behave as a free-living entity from fertilization to implantation and is capable of growing in culture in the absence of any exogenous growth factors (Biggers et al. 1988). However, the rate of growth of cleavage-stage mouse embryos in culture is density-dependent, suggesting that diffusible growth factors of embryonic origin may regulate this growth (Paria and Dey 1990). Early cleavage-stage mouse embryos can be combined or halved without effect on the size of neonates, demonstrating their extensive capacity for regulation (Kelly 1977; for review, see Pedersen 1986) and implying a process of embryonic growth regulation (Buehr and McLaren 1974; Lewis and Rossant 1982). During preimplantation stages the mouse embryo undergoes cleavage and differentiates into a blastocyst that possesses the precursors for the embryo proper (the inner cell mass) and the placenta (the trophectoderm). Com-

Present addresses: ${ }^{1}$ Departments of Obstetrics and Gynecology, and Cell, Molecular and Structural Biology, Northwestern University, Chicago, Illinois 60611 USA; ${ }^{2}$ Children's Medical Research Foundation, Royal Alexandra Hospital for Children, Camperdown, New South Wales 2050, Australia; ${ }^{3}$ Department of Medical Biochemistry, University of Calgary, Calgary, Alberta, Canada T2N 4N1.

${ }^{4}$ Corresponding author. paction, the epithelialization of the embryo at the eightcell stage, is required for the determination of these precursors (for review, see Cruz and Pedersen 1991) and is dependent on the transcription of the zygotic genome after its activation at the two-cell stage (Flach et al. 1982; Pikó and Clegg 1982). We have shown previously that cleavage-stage mouse embryos transcribe and translate mRNA for transforming growth factor (TGF)- $\alpha$, TGF- $\beta 1$, and platelet-derived growth factor-A chain, but not for nerve growth factor, basic fibroblast growth factor, epidermal growth factor, or granulocyte colony-stimulating factor (Rappolee et al. 1988a; for review, see Rappolee et al. 1990). Interleukin-6 and leukemia inhibitory factor/ differentiation-inhibiting activity are also expressed at the blastocyst stage (Conquet and Brulet 1990; Murray et al. 1990). However, no complete circuit of endogenous growth factor ligand and receptor has been elucidated in preimplantation mammalian embryos.

Insulin and its relatives constitute a family of growth factors that might be implicated in growth regulation of early embryos. Early mouse embryos bind insulin, which affects their rate of protein synthesis in culture (Harvey and Kaye 1988; Mattson et al. 1988). The insulin family includes insulin-like growth factor (IGF)-I, IGF-II, and 
insulin (two nonallelic genes) (Sara and Hall 1990). These factors are related by sequence and have insulin-like metabolic effects. In adult animals, insulin expression is regulated by glucose, and IGF-I expression is regulated by growth hormone, but the regulation of IGF-II is not well understood (Sara and Hall 1990).

There are three known insulin-like growth factor receptors. The IGF-II/mannose-6-phosphate receptor /also called the type- 2 receptor, but referred to in this report as the IGF-II receptor) binds IGF-II strongly, binds IGF-I weakly, but does not bind insulin at all (Roth 1988; Czech 1989|. It also binds glycoproteins containing mannose-6-phosphate moieties, but these proteins do not activate the $G$ protein-mediated signaling induced by the binding of IGF-II (Okamoto et al. 1990a,b). The IGF-I receptor (also called the type- 1 receptor or IGF-I/IGF-II receptor) and insulin receptors are related tyrosine $\mathrm{ki}$ nases activated by ligand binding. The IGF-I receptor is activated equally by IGF-II and IGF-I, but the insulin receptor is activated more strongly by insulin than by IGF-I (Roth 1988; Sakano et al. 1991). Purified insulin receptor isolated from placenta binds IGF-II nearly as well as insulin, but the mitogenic capacity of IGF-II for the insulin receptor is not known (Sakano et al. 1991). Mitogenic responses to IGF-II are mediated by the IGF-I receptor not by the IGF-II receptor (Kiess et al. 1987; Osborne et al. 1989; for review, see Czech 1989).

Postimplantation rodent embryos possess the IGF-II receptor (Smith et al. 1987; Senior et al. 1990) and the IGF-I receptor in greater quantities than the insulin receptor (Smith et al. 1987), but the relative roles of the IGFs and their receptors in early development are still unclear. IGF-II has been implicated in postimplantation mouse growth (DeChiara et al. 1990, 1991), but IGF-II transcripts have not been detected in mouse (Lee et al. 1990) or human (Brice et al. 1989; Ohlsson et al. 1989b) preimplantation embryos. IGF-II expression has been associated most closely with mesoderm (Heath and Shi 1986; Stylianopoulou et al. 1986, 1988; Beck et al. 1987; Han et al. 1987b), which arises at gastrulation.

Regulation of growth in early mammalian embryos might be modulated by genomic imprinting, the selective differential expression of genes initiated by a process of unknown mechanism during gametogenesis. IGF-II ligand is imprinted when inherited maternally, and IGFII receptor is imprinted when inherited paternally (DeChiara et al. 1990; Barlow et al. 1991).

In this study, we analyzed preimplantation zygotic mouse embryos for the expression and function of three ligands and receptors in the IGF family and examined parthenogenetic embryos for evidence of genomic imprinting at preimplantation stages.

\section{Results}

Preimplantation zygotic mouse embryos express IGF-II

We used the sensitive reverse transcription-polymerase chain reaction (RT-PCR) technique, which can detect as few as 10-100 mRNA transcripts in a single cell (Rap- polee et al. 1988a,b, 1989|, to determine whether embryos express transcripts for the insulin family members. IGF-II transcripts were detected first at the two-cell stage in samples of 10 embryos containing a total of $3 \mathrm{ng}$ of RNA (Pikó and Clegg 1982) and then increasingly through the blastocyst stage in samples containing up to 15 ng of total RNA (Fig. 1a,b). Insulin and IGF-I transcripts were not found before implantation (Fig. 1c,e). In contrast, an IGF-I signal was detected in 20 pg of macrophage mRNA (Fig. ld), and an insulin signal was detected in $20 \mathrm{pg}$ of pancreas mRNA (Fig. 1f). RT-PCR products were validated by restriction enzyme mapping, sequence analysis, and Southern blot analysis /data not shown). IGF-II transcripts were expressed at the late twocell stage when the zygotic genome is first transcribed and after much of the maternal contribution of transcripts has been degraded (Pikó and Clegg 1982; Schultz 1986).

The IGF-II gene gives rise to two mRNAs; the one expressed more ubiquitously does not code for a protein in reticulocyte lysate systems (Frunzio et al. 1986; Graham et al. 1986). Because the presence of growth factor mRNA cannot be equated with translation of the RNA to protein (Dinarello 1989), we analyzed blastocysts for the presence of IGF-II polypeptide immunologically. There was insufficient protein to detect metabolically labeled growth factors from mouse blastocysts by immunoprecipitation or immunoblotting (data not shown). However, polypeptides reacting with a polyclonal antibody to rat IGF-II were seen in all cells of the blastocyst by immunocytochemistry (Fig. 2). All staining was attenuated by preabsorbing the antibody with purified rat IGF-II. Nevertheless, these data do not necessarily indicate that all cells within the blastocyst are sites of IGF-II synthesis. It is possible that some cells produce IGF-II and that others take it up by endocytosis, because all cells of the blastocyst apparently produce IGF-II receptor, as judged by immunocytochemistry with anti-receptor antibodies (data not shown). We conclude that preimplantation mouse embryos begin to transcribe IGF-II soon after activation of zygotic transcription at the twocell stage and accumulate immunoreactive polypeptide at the blastocyst stage (Schultz 1986).

\section{Preimplantation mouse embryos express receptors for IGF-II}

Unfertilized eggs and zygotic embryos at the two-cell, four-cell, eight-cell, and blastocyst stages were assayed by RT-PCR for insulin receptors, IGF-I receptors, and IGF-II receptors. Transcripts for the IGF-II receptor were detected at the two-cell stage (Fig. 3a). IGF-I and insulin receptors were not expressed until after compaction, at the eight-cell stage (although in one of five experiments there was a weak signal for IGF-I receptor at the two-cell stage) (Fig. 3c,e); all receptors were detected in $\leqslant 2 \mathrm{ng}$ of control RNA (Fig. 3b,d,f). Taken together, these observations suggested that among the insulin family of growth factors, only IGF-II could potentially function as an endogenous ligand in preimplantation mouse embryos and 
a

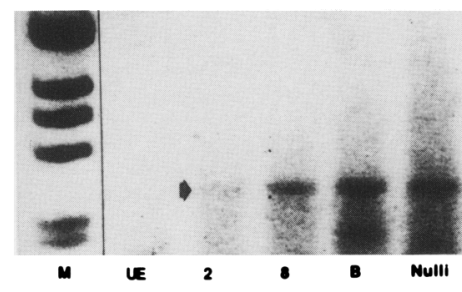

C
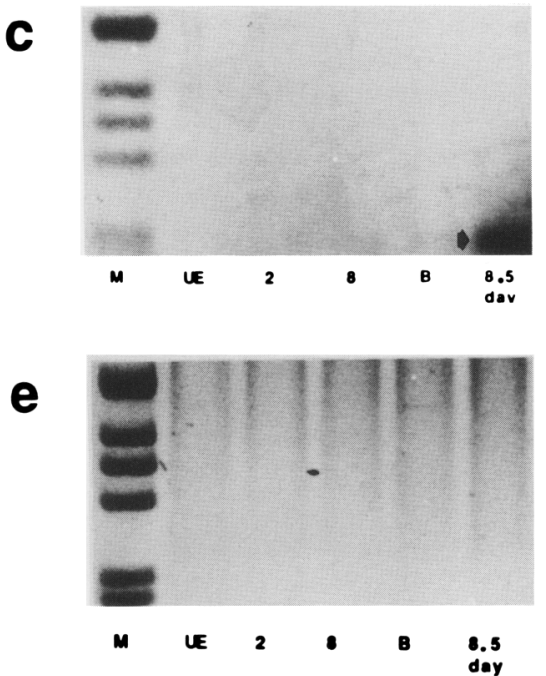

b

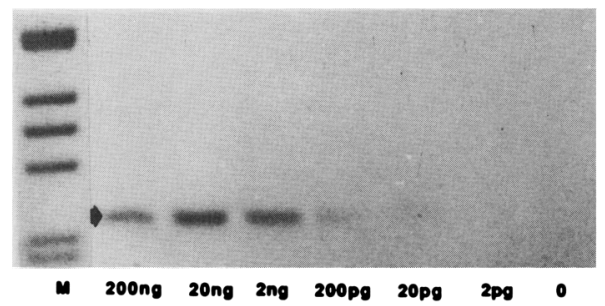

d
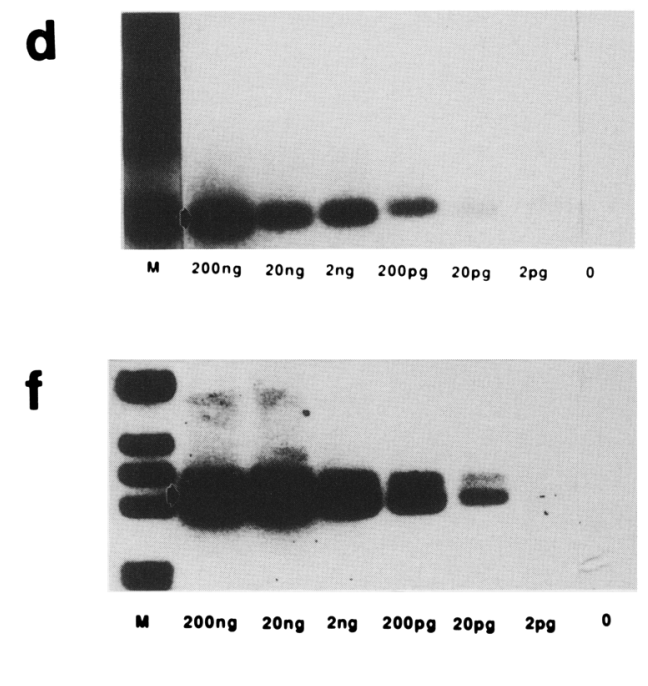

Figure 1. Expression pattern of mRNA transcripts for IGFs in preimplantation mouse embryos. Preimplantation mouse embryos were obtained in groups of 100-200 from superovulated females $24 \mathrm{hr}$ after injection of human chorionic gonadotropin [(UE) unfertilized one-cell, 36 hr p.c.; (2) two-cell, 60 hr p.c.; (8) eight-cell, 96 hr p.c.; (B) blastocyst, and (8.5 day) at 8.5 d.g.]. Whole-cell RNA was purified and reverse transcribed, and cDNA from $\sim 10$ embryos $/ \sim 3.5 \mathrm{ng} / 10$ unfertilized eggs, $2.4 \mathrm{ng} / 10$ two-cell, $6.9 \mathrm{ng} / 10$ eight-cell, 14.2 ng/10 blastocysts; Pikó and Clegg 1982) was amplified for 60 cycles of PCR and electrophoresed in agarose. Positive controls were 200 ng of whole-cell RNA from nullipotent embryonal carcinoma stem cells (Nulli) or 8.5-d.g. embryos. (a) IGF-II transcripts (266 bp); (b) 10 -fold dilution series of mRNA from differentiated F9 cells; (c) IGF-I transcripts $(210 \mathrm{bp})$; (d) dilution series of mRNA from endotoxinstimulated macrophages; $(e)$ insulin transcripts $(299 \mathrm{bp}) ;(f)$ dilution series of mRNA from pancreas. Arrows indicate the location of the PCR product. Data are shown as negative images of ethidium bromide-stained gels. In $b, d$, and $f$, amounts ranging from 20 pg through $2000 \mathrm{ng}$ of whole RNA was reverse transcribed and $2 \mathrm{pg}$ through $200 \mathrm{ng}$ (one-tenth of reverse transcription) was analyzed by PCR.

that it could act through the IGF-I receptor, the IGF-II receptor, or the insulin receptor.

\section{Receptors for IGF-II function in preimplantation mouse embryos}

It has been shown previously that insulin binds and stimulates mouse embryos soon after compaction (Harvey and Kaye 1988; Mattson et al. 1988) and that inner cell mass cells from mouse blastocyst outgrowths bind IGF-I, IGF-II, and insulin (Mattson et al. 1988). This indicates that one or more members of the insulin family of receptors must be functional during preimplantation mouse embryo development. We first determined the effect of adding recombinant human IGF-II to mouse embryos during culture from two-cell stage to blastocyst. Examination of sequential photographs of embryos cultured with IGF-II or insulin revealed no obvious morphological effects or modulation of the rate of progression through the cleavage stages to compaction; however, the time of cavitation was accelerated (data not shown). During the last $4 \mathrm{hr}$ of culture, $\left[{ }^{35} \mathrm{~S}\right]$ methionine was added and the blastocysts were assayed for incorporation of radiolabeled methionine into protein by precipitation with trichloroacetic acid (TCA). IGF-II increased methionine incorporation significantly $(P<0.05$, Student's $t$-test $)$ by 1.8- and 3.5-fold in two experiments (Fig. 4); IGF-I stimulated methionine incorporation to a lesser extent. In agreement with the results of Harvey and Kaye (1988), we also found that insulin increased the specific activity of radiolabeled proteins significantly $(P<0.05$, Student's $t$-test) by 2 - to 2.5 -fold in two experiments (Fig. 4). However, the patterns of $\left[{ }^{35} S\right]$ methionine-labeled proteins from untreated and IGF-II-treated embryos were qualitatively indistinguishable by one-dimensional SDS-polyacrylamide gel electrophoresis (data not shown). These observations show that IGF-II has a significant effect on preimplantation embryonic growth.

At the growth factor concentrations used in these first tests of function for embryonic receptors, it was not pos- 
Figure 2. Expression of IGF-II polypeptide in mouse blastocysts. Cultured mouse blastocysts were centrifuged onto coverslips and prepared for indirect immunofluorescence by using polyclonal antibody to rat IGF-II before $(a, b)$ and after $(c, d)$ absorption of the antibody with a 1000 -fold excess of rat IGF-II. $(a, c)$ Phase micrographs; $(b, d)$ fluorescence micrographs.
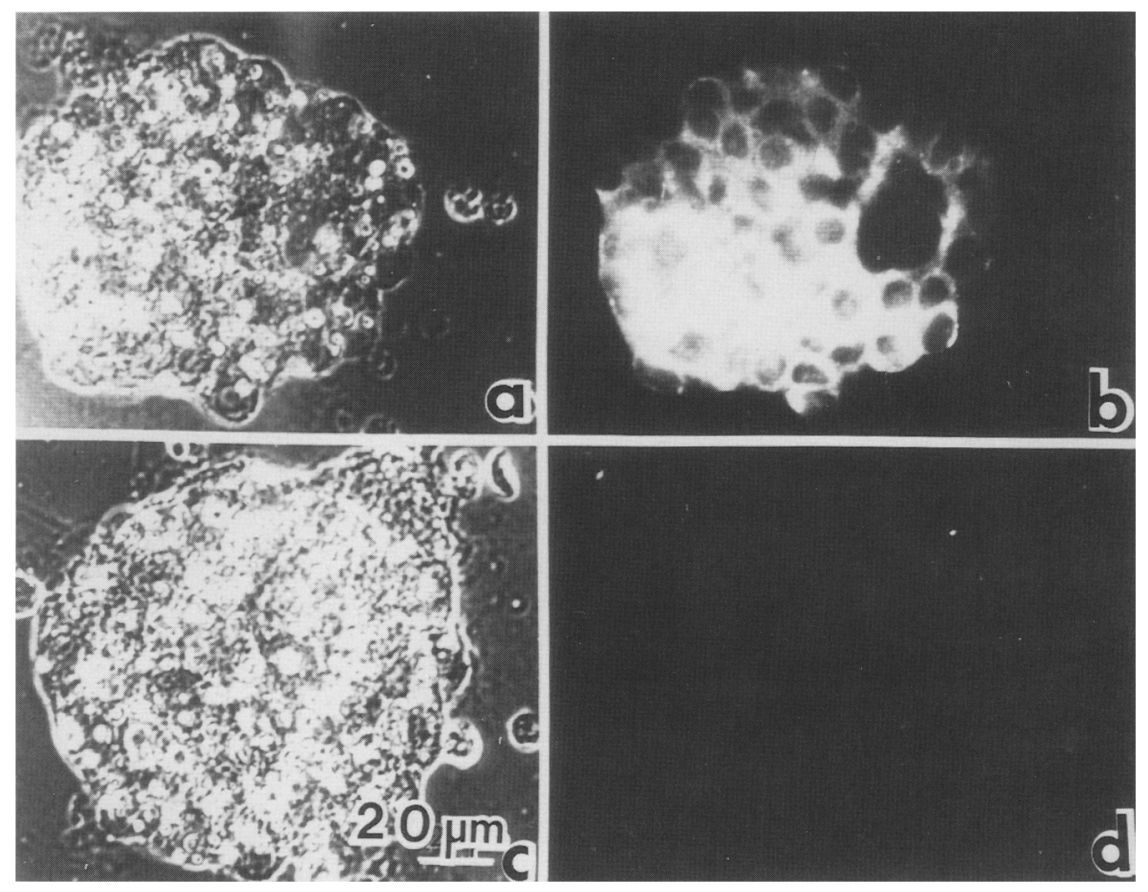

sible to determine whether the IGF-II receptor the IGF-I receptor, or the insulin receptor was mediating the effects of IGF-II on protein accumulation. Because no changes were seen in the rate of progress through early cleavage or compaction after IGF-II exposure, the IGF-II receptor is either not functional in the early cleavage stages or is not sufficient to regulate events in early development. We compared the effects of IGF-II, IGF-I, and [Leu ${ }^{27}$ ]IGF-II, a mutant form of IGF-II that binds strongly to the IGF-II receptor (Beukers et al. 1991), on the growth of preimplantation mouse embryos. Mouse embryos cultured from the two-cell to the blastocyst stage had increased numbers of cells after exposure to IGF-I or IGF-II but not after exposure to [Leu ${ }^{27}$ ]IGF-II (Fig. 5). Cell number increased significantly (1.2- to 1.4-fold in two experiments; $P<0.05$, Student's $t$-test) at concentrations of IGF-I and IGF-II that were near the $K_{\mathrm{d}}$ of the IGF-I receptor (Roth 1988; Czech 1989), but 10-fold higher concentrations of $\left[\mathrm{Leu}^{27}\right]$ IGF-II had no effect. Because these growth factors appeared to act only after compaction, these increases in cell number occurred in one to two cell divisions in the presence of a number of other endogenous growth factors (Rappolee et al. 1990) and thus are highly significant. These data suggest that IGF-II induces growth in preimplantation mouse embryos through the IGF-I receptor or the insulin receptor and not through the IGF-II receptor, which binds only to IGFII or [Leu ${ }^{27}$ ]IGF-II.

\section{Reduction in IGF-II expression by antisense oligonucleotides slows embryonic growth}

We then analyzed whether the endogenous embryonic IGF-II functions in embryonic growth. Antisense oligo- nucleotides have been used to reduce the expression and function of intracellularly expressed genes such as c-myc (Holt et al. 1988) and growth factors (Becker et al. 1989), and thus they provide a proven method for decreasing gene expression in preimplantation mouse embryos (Bevilacqua et al. 1988). We used sequence-specific oligonucleotides for IGF-II that were complementary for the coding region of the first 6 amino acids (MarcusSekura 1988; Stein and Cohen 1988). The preimplantation embryos tolerated the oligonucleotides well, and toxicity with control sense or random oligonucleotides was seen only above 100-200 $\mu \mathrm{M}$; with control oligonucleotides below $100 \mu \mathrm{M}$, the embryos grew at least as well as untreated embryos. However, a concentrationdependent effect of antisense oligonucleotides was seen between 1 and $100 \mu \mathrm{M}$, with a peak of sensitivity at 30 $\mu \mathrm{M}$. At this concentration, $\sim 10^{6}$ molecules of the sense or antisense IGF-II oligonucleotides were present at steady state in the blastocyst, as detected by autoradiography and liquid scintillation spectrometry (data not shown).

Culture of mouse embryos from the two-cell to the blastocyst stage with antisense IGF-II oligonucleotides in two separate experiments resulted in the loss of immunochemically demonstrable IGF-II antigen compared with embryos incubated with sense oligonucleotides, with an estimated average decrease in immunofluorescence of at least $75 \%$ (Fig. $6 \mathrm{a}-\mathrm{d}$ ). In contrast, the average amount of actin seen with rhodamine-phalloidin in two experiments was the same in embryos treated with either sense or antisense oligonucleotides (Fig. 6e,f). With normal rabbit serum, no antigens were detected (Fig. $6 \mathrm{~g}, \mathrm{~h})$. The amount of IGF-II mRNA demonstrable by quantitative RT-PCR analysis was reduced by antisense 
a

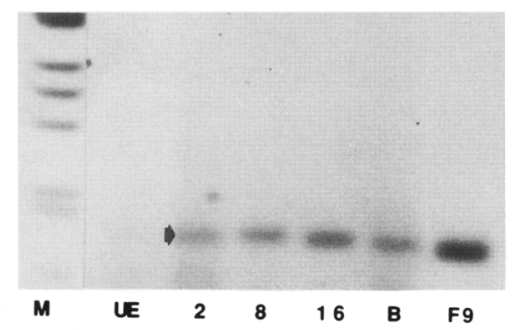

b

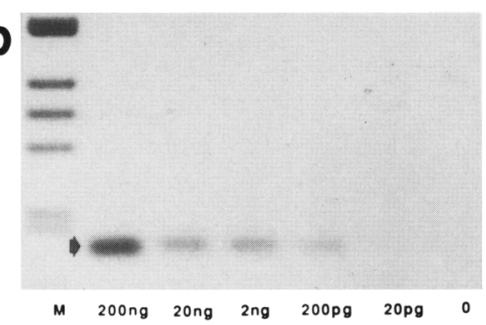

\section{C}

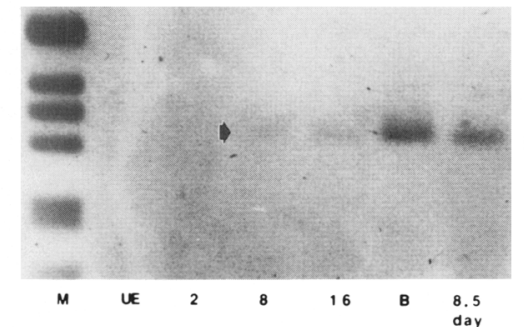

e

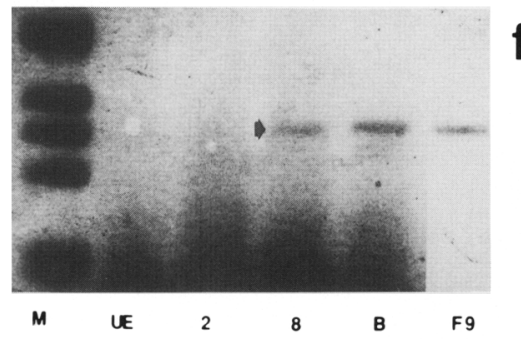

d

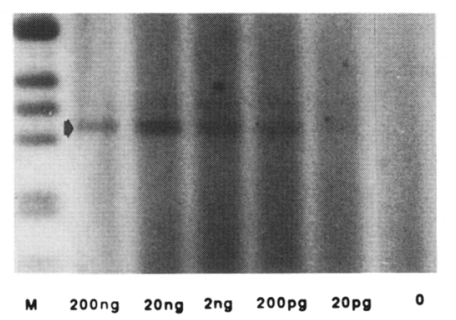

f

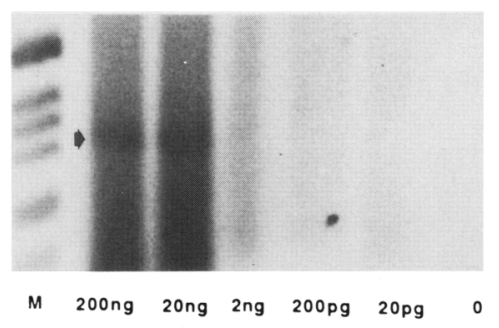

Figure 3. Expression pattern of mRNA transcripts for IGF receptors in preimplantation mouse embryos. Transcripts for IGF-II receptor (186 bp) $(a, b)$, IGF-I receptor (345 bp) $(c, d)$, and insulin receptor (319 bp $\mid(e, f)$ were assayed as described in the legend to Fig. 1. Dilution series for positive controls were obtained from differentiated F9 cells $(b, d)$ and endotoxin-stimulated macrophages $(f)$. As in Fig. 1, whole RNA from 10 embryos at each stage was examined; abbreviations are also the same. Data are shown as negative images of ethidium bromide-stained gels.

IGF-II oligonucleotides, whereas the amount of glyceraldehyde-3-phosphate dehydrogenase (GAPDH) mRNA was unaffected (Fig. 7a). The effects of antisense IGF-II oligonucleotides seemed specific: A delay in the onset of blastocyst formation, assayed by appearance of cavitation, was also seen with a second pair of sense and antisense oligonucleotides specific for IGF-II (Fig. $7 \mathrm{~b}$ ). The proportion of embryos reaching the blastocyst stage after 48 and $72 \mathrm{hr}$ also decreased significantly $(P<0.05$, Student's $t$-test) with the second antisense oligonucleotide but was not affected by the second sense oligonucleotide. Preimplantation mouse embryos cultured with antisense oligonucleotides from the two-cell to the blastocyst stage grew significantly more slowly $\mid P<0.05$, Stu-

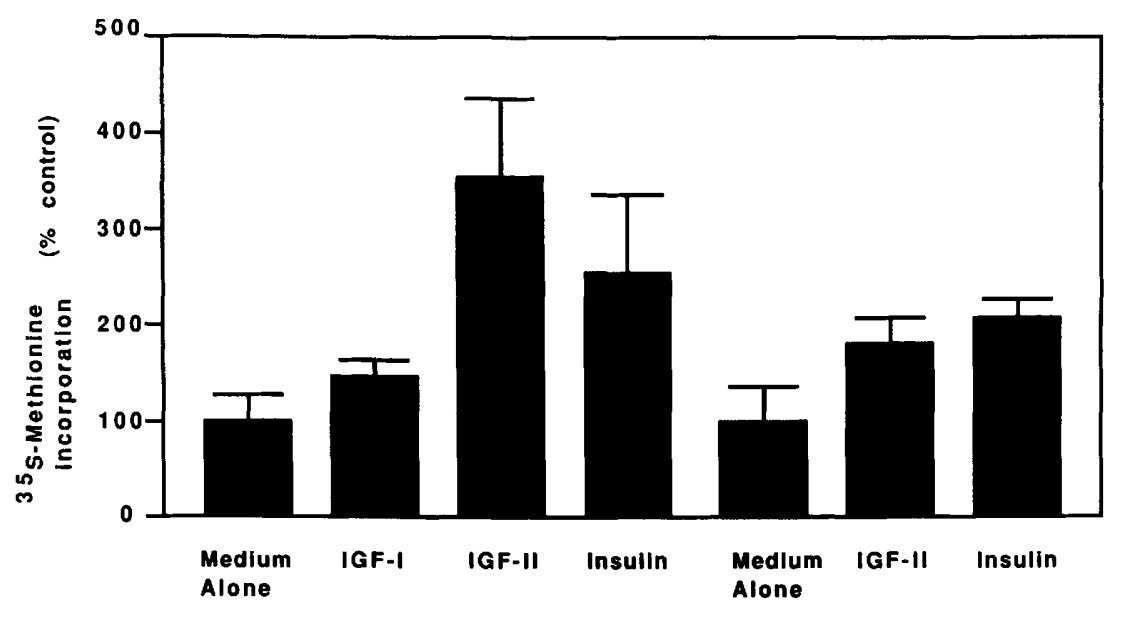

Experiment 1
Figure 4. Stimulation of protein synthesis by IGF-II in preimplantation mouse embryos. Mouse embryos were cultured from the twocell stage for $48 \mathrm{hr}$ to the blastocyst stage with 100 nM IGF-II, IGF-I, or insulin. During the last $4 \mathrm{hr}$ of culture, blastocysts were incubated with $1 \mathrm{mCi} / \mathrm{ml}$ of $\left[{ }^{35} \mathrm{~S} /\right.$ methionine $(3000 \mathrm{Ci} / \mathrm{mmole})$. Incorporation into proteins was measured by liquid scintillation spectrometry after acid precipitation. Protein synthesis was enhanced significantly after insulin, IGF-II, and IGF-I, compared with medium alone (Student's $t$-test; $P<0.05$ ). Three independent experiments were performed, with 60 blastocysts in each experiment. Results of two experiments are shown. The incorporation of $\left.{ }^{35} \mathrm{~S}\right]$ methionine into untreated embryos was 826 and $1250 \mathrm{cpm}$ in the two experiments. The Bachem preparation of IGF-I was used in these experiments. Bars, mean \pm S.D. 


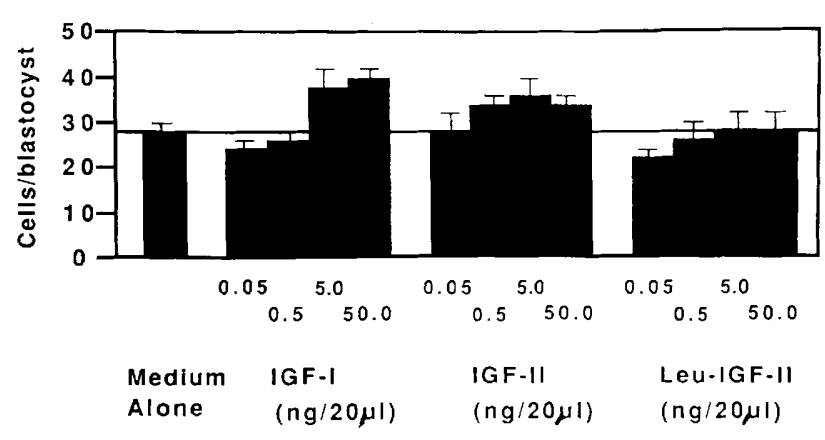

Figure 5. Demonstration that IGF-II stimulates cell growth in preimplantation mouse embryos through the IGF-I receptor. Mouse embryos were cultured from the two-cell stage through the early blastocyst stage in medium alone or with $0.05-50$ $\mathrm{ng} / 20 \mu 1$ of IGF-I, IGF-II, or [Leu ${ }^{27}$ ]IGF-II, fixed onto coverslips with ethanol-acetic acid, and stained with Hoechst 33258, and nuclei were counted. Twenty embryos were counted from each group. The two highest concentrations of IGF-I and the three highest concentrations of IGF-II had significantly higher effects on growth than did medium controls (Student's t-test; $P<0.05$ ). The Amgen preparation of IGF-I was used in these experiments. The decrease in cell number at the highest dilutions was probably the result of accumulation of plasticizer contaminants during the serial dilution of the proteins and masked the effects at low concentrations but still permitted observation at higher concentrations. The decreased cell number at the highest dilution was the result of accumulation of contaminants during serial dilutions.

dent's $t$-test) (Fig. 7 b) and had an average of $20 \%$ fewer cells than those cultured with sense oligonucleotides (Fig. 7c).

Cytotoxicity did not account for the decreased cell number and slowing of cavitation, because when the antisense oligonucleotide-treated embryos were cultured an additional $24 \mathrm{hr}$ beyond the $48-$ to $72-\mathrm{hr}$ time point, the fraction reaching late blastocyst stage was indistinguishable from that of sense oligonucleotide-treated embryos. Moreover, exogenous IGF-II reversed the deficiency in embryo growth that resulted from the reduction in endogenous IGF-II; the number of cells in mouse embryos cultured with antisense IGF-II oligonucleotides in the presence of recombinant IGF-II was significantly greater than that in embryos cultured with antisense IGF-II oligonucleotides alone (Fig. 7c).

\section{Imprinting disrupts the IGF-II growth circuit in parthenogenetic mouse embryos}

Imprinting of the IGF-II gene has been observed previously by DeChiara et al. (1990). To determine whether imprinting is detectable in preimplantation embryos, we exploited the process of parthenogenesis to obtain embryos that have a diploid genome of only maternal origin; this is produced by suppression of cytokinesis in activated oocytes. In contrast to zygotic embryos (Fig. 1), no IGF-II transcripts were apparent in preimplantation parthenogenotes (Fig. 8a), extending the observation by
DeChiara et al. (1990) that the maternally inherited IGFII gene is imprinted in later development. However, actin gene transcripts were detected throughout preimplantation development in both zygotic embryos and parthenogenotes (Fig. 8b).

Peri-implantation parthenogenotes did not express the IGF-I receptor gene or expressed it only weakly (Fig. 8c). These data indicate that the IGF-I receptor, or a gene regulating it, may also be imprinted when inherited maternally.

The number of cells in parthenogenetic blastocysts treated with $50 \mathrm{~nm}$ IGF-II $(95 \pm 10.8 \%$ control, for two experiments) for $48 \mathrm{hr}$ was not significantly different from that in untreated parthenogenotes $(P \leqslant 0.846$; Student's $t$-test); the number of cells in zygotic blastocysts treated with IGF-II was $135 \pm 8.6 \%$ control $(P \leqslant 0.005)$. This is in agreement with the hypothesis that IGF-II may act as a mitogen by the IGF-I receptor, but further experiments on the mitogenic effects of IGF-II through the insulin receptor and the imprinting status of the insulin receptor are required.

Transcripts for the IGF-II receptor were expressed equally in zygotes and parthenogenotes (Fig. 8d), in keeping with previous observations that this gene is imprinted when inherited paternally (Barlow et al. 1991). These data suggest that the endogenous growth factor

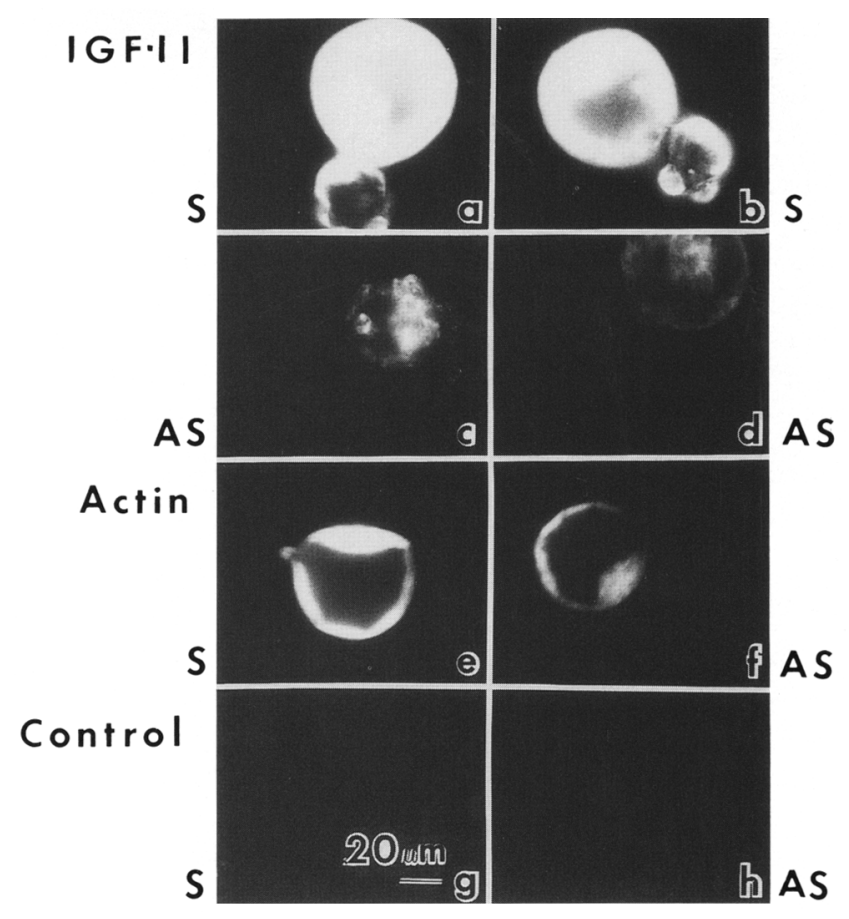

Figure 6. Effect of antisense IGF-II oligonucleotides on endogenous IGF-II antigen in preimplantation mouse embryos. Preimplantation mouse embryos cultured from the two-cell stage with sense $(S)(a, b, e, g)$ or antisense (AS) $(c, d, f, h)$ oligonucleotides were fixed and subjected to indirect immunofluorescence with polyclonal anti-rat IGF-II $(a, b, c, d)$ or nonimmune rabbit serum (NRS) $(g, h)$ or stained with rhodamine-phalloidin to detect actin $(e, f)$. 


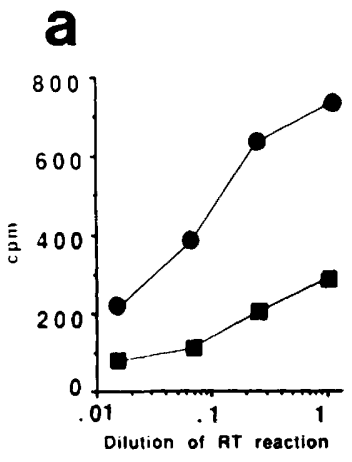

IGF-II transcript

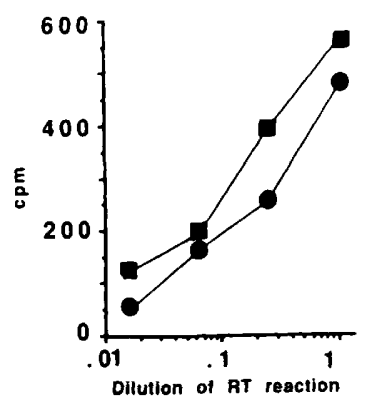

GAPDH transcript

Figure 7. Effect of antisense IGF-II oligonucleotides on IGF-II expression and function in preimplantation mouse embryos. (a) Fifty two-cell mouse embryos were incubated with $30 \mu \mathrm{M}$ sense or antisense IGF-II oligonucleotides for $48 \mathrm{hr}$; their RNAs were then purified and assayed for expression of IGF-II transcripts (left) or GAPDH transcripts (right) by RT-PCR in the presence of ${ }^{32} \mathrm{P}$-labeled oligonucleotide primers. (O) Embryos treated with sense oligonucleotides; $(\square)$ embryos treated with antisense oligonucleotides. $(b)$ Preimplantation mouse embryos were incubated with 30 $\mu \mathrm{M}$ sense or antisense IGF-II oligonucleotides for 48 $\mathrm{hr}$; they were then photographed, and the percentage of cavitated blastocysts was determined. Initiation codon oligonucleotides were used in experiments 1 and 2 . In experiment 3 , the oligonucleotides made for PCR were used. Both designs of antisense IGF-II oligonucleotides lowered the percentage of cavitated blastocysts significantly (Student's $t$-test; $P<0.001$ ). (c) Preimplantation mouse embryos were incubated with $30 \mu \mathrm{M}$ sense or antisense IGF-II oligonucleotides for $48 \mathrm{hr}$, with or without $10 \mathrm{nM}$ recombinant IGF-II. Blastocysts were then fixed and stained with Hoechst 33258 , and the nuclei were counted. Exogenous IGF-II reversed the attenuated growth of blastocysts caused by antisense IGF-II oligonucleotides $(P<0.05)$.

circuit in early embryos that is dependent on IGF-II is disrupted by imprinting in parthenogenetic embryos.

\section{Discussion}

We have found that IGF-II transcript and polypeptide and transcripts for its receptors are expressed and form an endogenous circuit that is functional during normal preimplantation mouse embryogenesis. It is probable that endogenous IGF-II mediates growth through the IGF-I receptor or the insulin receptor rather than the IGF-II receptor, because IGF-II and IGF-I, but not [Leu ${ }^{27}$ ]IGF-II, increased cell number in preimplantation mouse embryos in a concentration range suggesting activation of IGF-I receptor or insulin receptor. Although both IGF-II ligand and receptors for IGF-II are expressed before compaction, reduction of endogenous IGF-II or addition of exogenous IGF-II had no apparent effect on morphology at the earliest stages, as judged by cell divisions measured during precompaction cleavage or by the timing of

b
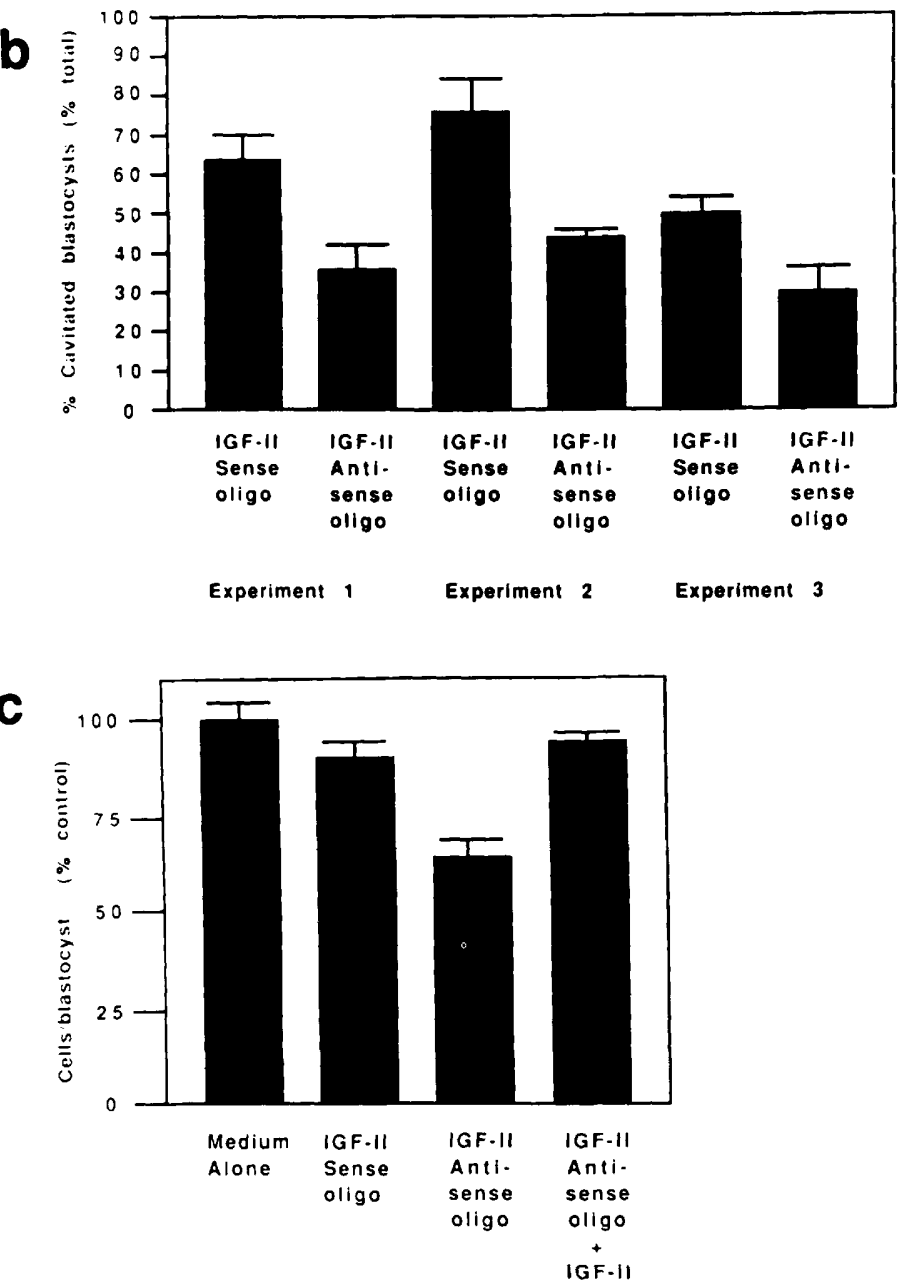

compaction. All effects resulting from perturbing this pathway were on growth and metabolism measured after the morula stage. Incorporation of radiolabeled methionine and growth rate were affected significantly by treatments that increased or decreased the effects of IGF-II in cultured preimplantation embryos. Recent IGF-II genetargeting experiments by DeChiara and co-workers (1990) demonstrated a $40 \%$ reduction in birth weight of IGF-II-mutant neonates, similar to the reduction in growth (measured by reduction in cells per blastocyst) that we observed in preimplantation embryos in the presence of antisense IGF-II oligonucleotides, but these workers did not study whether there was a decrease in the rate of early embryonic development of embryos that were heterozygous or homozygous for the mutation (DeChiara et al. 1991).

As we found that transcripts for IGF-I and insulin ligands are not expressed in cleavage-stage embryos, yet their receptors function (Harvey and Kaye 1989, 1991; Gardner and Kaye 1991), we speculate that maternal 


\section{Zygote Parthenogenote}

Figure 8. IGF-II and IGF receptor expression in parthenogenetic embryos. Parthenogenetic embryos were generated by ethanol activation, followed by suppression of second polar body emission by cytochala$\sin D$, and cultured to various stages before processing and assay of mRNA transcripts by RT-PCR. Normal zygotic embryos were generated and assayed for mRNA transcripts as described in Figs. 1 and 3. The expression of mRNA transcripts for $(a)$ IGF-II, $(b)$ actin, $(c)$ IGF-I receptor, and $(d)$ IGF-II receptor in unfertilized egg (UE), eight-cell (8), blastocyst stage-embryos (B), and 3- and 7-day blastocyst outgrowths $(O G)$ is shown in zygotic (left) and parthenogenetic (right) embryos. cDNA reverse-transcribed from RNA from about five embryos was used for the PCR analysis in each lane. Data are shown as negative images of ethidium bromidestained gels. a

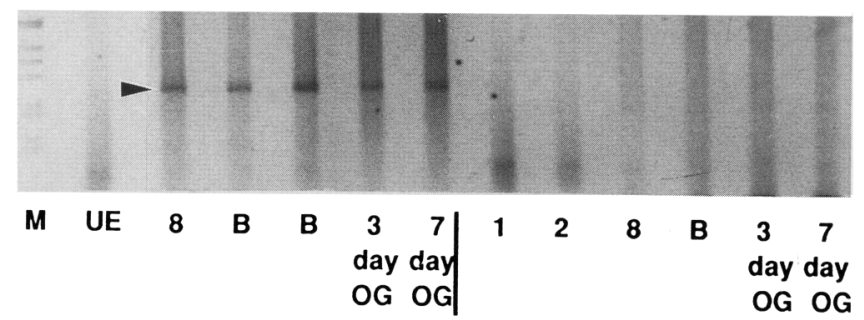

b

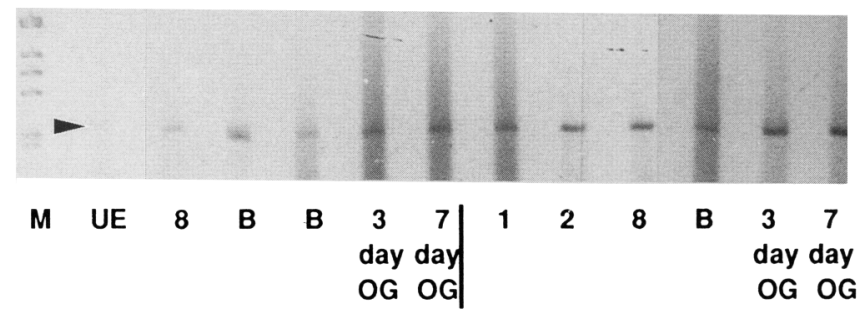

C

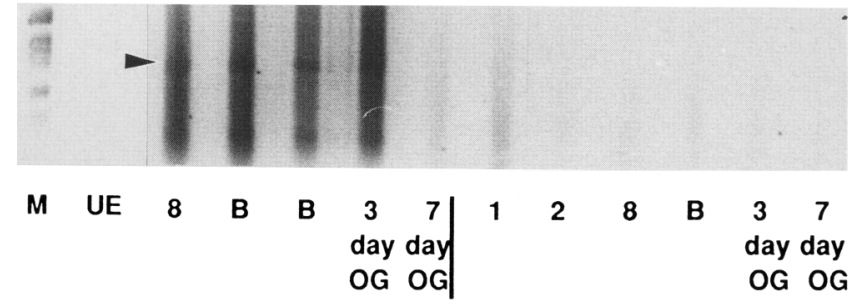

d

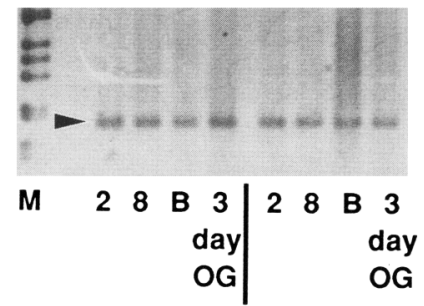

IGF-II

receptor
IGF-I and insulin form a maternal-embryonic pathway that also modulates cell growth of preimplantation mouse embryos. IGF-I is found in the uterine fluid of some mammals (Ko et al. 1991). This idea is supported by recent evidence that insulin increases cell number in the inner cell mass and that there are fewer cells in the inner cell mass of blastocysts from diabetic animals (Liu et al. 1989; Harvey and Kaye 1990; Pampfer et al. 1990), although direct evidence for in vivo effects is lacking.

We showed previously that TGF- $\alpha$ is transcribed and translated in cleavage-stage mouse embryos (Rappolee et al. 1988a), and we have also observed that antisense oligonucleotides specific for TGF- $\alpha$ slow the growth of preimplantation mouse embryos, whereas exogenous TGF- $\alpha$ increases their protein synthetic rate (D.A. Rappolee and Z. Werb, unpubl.). TGF- $\alpha$ did not regulate morphogenetic events such as compaction but, rather, altered the growth rate, as reported recently for growth factors acting through the epidermal growth factor receptor (Paria and Dey 1990). These results suggest that endogenous growth factors such as IGF-II and TGF- $\alpha$ do not regulate differentiation events in preimplantation mouse embryos but regulate metabolic processes that may modulate cell proliferation rates. Limited increases in protein synthesis caused by addition of several growth factors (IGF-II, insulin, or TGF- $\alpha$ ) and limited decreases in cell growth rate caused by attenuating the expression of IGF-II or TGF- $\alpha$ alone suggest that growth is regulated in preimplantation embryos through multiple, partially redundant, growth factor circuits. Further experiments are required to define this redundancy in vitro and in vivo.

The use of a sensitive method such as RT-PCR raises a question about the biological relevance of low transcript levels. Previous reports have shown that IGF-II mRNA is not expressed in mouse or human blastocysts assayed by in situ hybridization (Beck et al. 1987; Ohlsson et al. 1989b; Lee et al. 1990). We have found that IGF-II is expressed in mouse embryos when assayed by the RT-PCR technique, that the polypeptide is expressed as assayed by immunofluorescence, and that 
IGF-II expression has biological function. We have found previously that TGF- $\alpha$ mRNA is expressed in mouse embryos at 7.5 days of gestation (d.g.) (Rappolee et al. 1988a) when equivalent-stage rat embryos were found to be negative by in situ hybridization (Han et al. 1987a). It therefore seems likely that RT-PCR can detect biologically significant levels of growth factor mRNA not detected by in situ hybridization. This should not be surprising, because a growth factor receptor with a $K_{\mathrm{d}}$ of $10^{-13}$ is activated by a polypeptide concentration of about one molecule per fibroblast cell volume (assuming that a fibroblast has a volume of $\sim 10^{4} \mu \mathrm{m}^{3}$ ) and growth factors normally act within a few cell diameters of their source (Deuel 1987). Other genes such as c-myc reach maximum levels of five transcripts per cell during a response to optimal levels of platelet-derived growth factor (Deuel 1987). Transcripts of developmentally important genes such as the limb deformity gene in the apical ectodermal ridge in mouse embryos (Zeller et al. 1989) are also not detected by in situ hybridization. Therefore, even very small numbers of mRNA transcripts might be biologically significant if they are involved in gene regulation or participate in signaling cascades.

When exogenous IGF-II ligand was added simultaneously with IGF-II antisense oligonucleotides, the effects caused by reduction of the endogenous IGF-II were reversed. Thus, the temporal or spatial distribution of endogenous IGF-II can be mimicked, in part, by exogenous IGF-II. It is likely that antisense IGF-II, which attenuates the expression of the endogenous IGF-II, slows embryonic growth through a specific mechanism. The coding sequence of the first 6 amino acid residues of IGF-II is not homologous with that of any other genes expressed in the preimplantation embryo, and two different antisense IGF-II oligonucleotides produced similar effects, confirming that these effects are specific.

Because IGF-II clearly did not account for all the cell proliferation in the early embryo, it is likely that other growth factors are involved. To assess whether various combinations of growth factors mediate any absolute effects on differentiation or growth, we must determine how they interact. Because at least 12 growth factor mRNAs are expressed during preimplantation mouse embryogenesis (Rappolee et al. 1988a, 1990; Murray et al. 1990; unpubl.), this is not a simple task. New approaches to eliminating growth factors selectively must be perfected to resolve their roles. Although antisense oligonucleotides cause cytotoxicity in embryos at relatively low concentrations $(100-200 \mu \mathrm{M})$, several could be used at the $30 \mu \mathrm{M}$ optimal concentrations observed in this study to attenuate expression of multiple growth factors simultaneously. Alternatively, growth factors can be added in combination or heterologous growth factors can be added with antisense IGF-II to test for redundancy of action; or growth factors can be deleted by homologous recombination (DeChiara et al. 1990), after which multiply homozygous mutants could be generated to investigate the roles of growth factors that act through redundant circuits.

That control of growth in early pre- and postimplan- tation mammalian embryos is regulated by genomic imprinting might be important from both developmental and evolutionary perspectives. Developmentally, expansion of different lineages of cells must be timed properly and maintained in proportion both intraembryonically and between the embryonic and maternal tissues. That imprinting is manifested from the two-cell stage, when zygotic transcription first occurs, suggests that the mechanisms for transcriptional regulation of these genes, at the level of either chromatin or DNA modification, are already stereotyped and in place when the genome is activated, much earlier than the mechanisms involved in X-chromosome inactivation (Lock et al. 1987; for review, see Grant and Chapman 1988). Evolutionarily, it has been suggested that imprinting might occur because of conflicting parental interests in the growth rates of offspring in plants and viviparous organisms; male gene transmission is favored by fast embryonic growth in competition with other males, whereas female gene transmission is favored by maximizing $F_{1}$ generation group size in competition with other females (Haig and Westoby 1989). In plants, the growth of the endosperm, the organ that acquires nutrients for the zygote, is under paternal control and is maternally imprinted (for review, see Haig and Westoby 1989). In mammals, the growth of the placenta, the organ that acquires nutrients for the zygote or the embryo proper, would be predicted to be under paternal control. Positively acting elements in early embryonic growth circuits would be predicted to be paternally transcribed, and negatively acting elements would be predicted to be maternally transcribed. It is interesting to note that IGF-II ligand and receptor and IGF-I receptor are highly expressed in trophectoderm, the precursor to placenta, soon after implantation of rodent embryos, and that IGF-II functions in a paracrine manner in human placentation (Rotwein et al. 1987; Stylianopoulou et al. 1988; Ohlsson et al. 1989a,b; Senior et al. 1990).

The hypothesis of Haig and Graham (1991) predicts that imprinting of growth factors such as IGF-II, IGF-II receptor, and IGF-I receptor might regulate embryonic growth in mammals in utero. Our results showing imprinting of the IGF-I receptor and IGF-II ligand when inherited maternally are consistent with this hypothesis, but we cannot rule out the possibility that genomic imprinting of other growth factors and receptors may function in maintaining balance in the proportion and timing of expansion of cell lineages in the embryo. Further studies on the expression, function, and imprinting status of other elements in IGF growth circuitry (e.g., IGF-binding proteins $\mid$, and of other growth factor circuits, may delineate these hypotheses. The analysis of genes expressed in uniparental parthenogenetic and androgenetic embryos may serve as a rapid, general method for identifying genomically imprinted genes (Pedersen et al. 1992).

It is notable that the IGF-II/mannose-6-phosphate receptors in chicken and Xenopus do not bind IGF-II /Clairmont and Czech 1989) and thus may function only in the transport of proteins targeted for lysosomes, whereas mammalian IGF-II/mannose-6-phosphate receptors bind 
IGF-II as well as mannose-6-phosphate-rich proteins (MacDonald et al. 1988) through different extracellular domains. It has been hypothesized that the IGF-II receptor in mammals suppresses growth by removing extracellular IGF-II (Haig and Graham 1991). Because of these evolutionary considerations, it will be interesting to evaluate the structure of the IGF-II receptor and its function in early embryogenesis in greater detail. There is evidence that IGF-II can stimulate growth in cells only after stimulation by other growth factors /Nishimoto and Kojima 1989), and that this effect may depend on $\mathrm{Ca}^{2+}$ influx, which depends on IGF-II binding to a $\mathrm{G}_{\mathrm{i}} 2$ binding IGF-II/mannose-6-phosphate receptor (Nishimoto and Kojima 1989; Okamoto et al. 1990a,b). However, the $\mathrm{Ca}^{2+}$-dependent mitogenic signal may also be mediated by IGF-II stimulation of the IGF-I receptor (Nishimoto and Kojima 1989). Our data strongly suggest that the IGF-II receptor is not the transducer of the mitogenic signal of endogenous IGF-II. The mitogenic signal of IGFII might be transduced by the IGF-I receptor or insulin receptor. The insulin receptor (Sakano et al. 1991) and IGF-I receptor (Roth 1988) can bind IGF-II nearly as well as their cognate ligands. It is not clear from our data whether the mitogenic activity of IGF-II in embryos is transduced by the IGF-I or insulin receptors, but attenuation of the expression of these receptors may distinguish between these possibilities.

Our data are the first to show directly that an endogenous growth factor plays a role in cell proliferation during the earliest stages of mouse development. Our results complement the analysis of long-term effects of IGF-II ligand on later embryonic and fetal growth in animals containing a mutant IGF-II gene (DeChiara et al. 1990). However, our understanding of the role of IGF-II in preimplantation mouse embryogenesis will require further studies. It is possible that growth rates during peri-implantation development are decisive in the establishment and proliferation of the extraembryonic lineages and, thereby, in the subsequent growth rate of the fetus. Still to be evaluated are synergism with other growth factors, signal transduction and gene induction by embryonic IGF-II, and location and function of the IGF-binding proteins in peri-implantation mouse embryos.

\section{Materials and methods}

\section{Materials}

Amplitaq DNA polymerase was purchased from Perkin-Elmer Cetus. Restriction enzymes and T4 polynucleotide kinase were purchased from New England BioLabs and Bethesda Research Laboratories (BRL). Radioisotopes were obtained from New England Nuclear. Moloney murine leukemia virus (MMLV) reverse transcriptase and Superscript MMLV reverse transcriptase were obtained from BRL. Antisense, sense, and PCR oligonucleotides were obtained from the University of California at San Francisco (UCSF) Biomolecular Resource Center or synthesized in our laboratory on an Applied Biosystems PCR-Mate oligosynthesizer. Biosynthetic insulin and IGF-II were gifts of Eli Lilly, and recombinant human IGF-II and IGF-I were purchased separately from Bachem. Polyclonal rabbit anti-rat IGF-II antibody and rat IGF-II/multiplication stimulation activity (MSA) were gifts of P. Nissley (National Institutes of Health). $\left[\mathrm{Leu}^{27}\right]$ IGF-II and recombinant IGF-I (Amgen) were the gifts of R. Rosenfeld (Stanford University). The IGF-I from Bachem was of lower specific activity than that from Amgen.

\section{Mouse eggs and embryos}

Standard techniques were used for obtaining eggs and zygotes (Hogan et al. 1986). Female CD-1 or CF-1 mice (6-10 weeks old, Charles River) were injected with 10 IU of pregnant mares' serum gonadotropin (Equitech), followed by an injection $44-48 \mathrm{hr}$ later of $5 \mathrm{IU}$ of human chorionic gonadotropin (hCG, Serono). After the second injection, females were housed overnight with $\mathrm{C} 57 \mathrm{BL} / 6 \mathrm{~J} \times \mathrm{SJL} / \mathrm{J} \mathrm{F}_{1}$ hybrid males (Jackson Laboratories). Embryos were obtained at the following stages: one-cell [12 hr postcoitum (p.c.)), two-cell (36 hr p.c.), four-cell (48 hr p.c.), eightcell $(60 \mathrm{hr}$ p.c.), and blastocyst (84-96 hr p.c.). Unfertilized eggs were flushed from the oviducts of superovulated females, and later embryos were dissected from the uteri of females 17.5 or 8.5 d.g.). Embryos were flushed from the uteri or oviducts of mice with flushing medium-I (FM-I) (Spindle 1980) containing 3 $\mathrm{mg} / \mathrm{ml}$ of bovine serum albumin. The embryos were then washed through 6 drops of FM-I. Mature oocytes/unfertilized eggs were flushed from oviducts $18 \mathrm{hr}$ after hCG injection and then treated with hyaluronidase to remove adherent cumulus cells (Hogan et al. 1986). All eggs and embryos were sorted and freed of debris under a dissecting microscope.

\section{Parthenogenetic embryos}

Parthenogenetic activation of mouse oocytes was performed essentially as described by Barton et al. (1987), with minor modifications (K.S. Sturm, M.L. Flannery, and R.A. Pedersen, unpub1.). Briefly, C57BL/6J $\times \mathrm{CBA} / / \mathrm{F}_{1}$ female mice were induced to superovulate by injection of pregnant mares' serum gonadotropin followed by hCG $48-50 \mathrm{hr}$ later. Ovulated oocytes were activated 19-21 hr after hCG injection. Mature oocytes were activated in embryo culture medium (TE) (Spindle 1990) containing $6 \%$ ethanol (vol/vol) and $50 \mu \mathrm{M}$ EDTA for $4.5 \mathrm{~min}$, washed through FM-I, and transferred to TE containing $50 \mu \mathrm{M}$ EDTA and $0.5 \mu \mathrm{g} / \mathrm{ml}$ of cytochalasin D for $5 \mathrm{hr}$ to block extrusion of the second polar body. The parthenogenetic embryos were then washed through FM-I, and intact embryos were transferred in groups of 20 to individual drops of TE containing $50 \mu \mathrm{M}$ EDTA and cultured at $37^{\circ} \mathrm{C}$. The efficiency of activation, determined from two-cell parthenogenetic embryos at $24 \mathrm{hr}$, was $65-85 \%$. Control zygotic embryos were produced by mating $F_{1}$ females with $F_{1}$ males. Parthenogenetic outgrowths were cultured in outgrowth medium (Spindle 1990) for 3-7 days after hatching of blastocysts.

\section{Embryo culture}

For each analysis, 30-40 embryos were cultured from the twocell stage in CZB medium (Chatot et al. 1989) or 20 embryos/ 20- $\mu$ l drop in TE (Spindle et al. 1990) under paraffin oil (Aldrich) to the blastocyst stage. All experiments were performed at least twice.

\section{Biosynthetic labeling of embryos}

Two-cell embryos (400-600) were incubated for $48 \mathrm{hr}$ in TE alone or in TE with $100 \mathrm{nM}$ IGF-II, insulin (Eli Lilly), or IGF-I (Bachem). For the last $4 \mathrm{hr}$, embryos were incubated with or 
without fresh growth factors and $1 \mathrm{mCi} / \mathrm{ml}$ of $\left[{ }^{35} \mathrm{~S}\right]$ methionine (3000 Ci/mmole) as described previously (Brenner et al. 1989). At the end of the labeling period, embryos were washed through 8 drops of TE and duplicate samples from triplicate drops precipitated onto glass filters by using $6 \% \mathrm{TCA}$ (wt/vol), and dried and assayed by liquid scintillation spectrometry. In some experiments, the washed embryos were solubilized in loading buffer and applied directly and proteins were separated by $12 \%$ SDSpolyacrylamide gel electrophoresis and analyzed by fluorography.

\section{RNA preparation}

A microadaptation (Rappolee et al. 1988a, 1989) of the guanidine isothiocyanate (GuSCN)-CsCl gradient ultracentrifugation technique was used to prepare total RNA from 100-200 embryos (Chirgwin et al. 1979). Embryos flushed from the genital tract at specific stages or cultured to specific stages were washed though 6 drops of FM-I, solubilized in $100 \mu \mathrm{l}$ of GuSCN containing $20 \mu \mathrm{g}$ of Escherichia coli rRNA (Boehringer Mannheim), and layered over $100 \mu \mathrm{l}$ of $5.7 \mathrm{M} \mathrm{CsCl}$ and centrifuged for $2 \mathrm{hr}$ at $80,000 \mathrm{rpm}$ in a TL-100A rotor in a Beckman TL-100 benchtop ultracentrifuge. Yields of RNA were based on carrier amount and ranged from $35 \%$ to $80 \%$. RNA used for positive controls was isolated from macrophages or retinoic acid-treated F9 cells, as described previously (Rappolee et al. 1988b; Brenner et al. 1989; Hahnel et al. 1990). The concentration of RNA was determined by measurement of absorbance at $260 \mathrm{~nm}$.

\section{$R T-P C R$}

RT-PCR was performed essentially as described previously (Rappolee et al. 1988a,b, 1989). Briefly, RNA was reverse transcribed with MMLV reverse transcriptase or Superscript MMLV reverse transcriptase primed with $0.2 \mu \mathrm{g}$ of random hexanucleotides (Pharmacia) or $0.5 \mu$ g of 12 - to 18 -mer oligo(dT) (Collaborative Research) with 100 units of enzyme in a 20- $\mu$ l mixture. In early studies on IGF-II expression, reaction mixtures were heat denatured and flash cooled; 50 units of additional buffered Superscript MMLV was added, and the RT mixture was reincubated. The proportion of the RT mixture that was equivalent to 10 embryos was added to sequence-specific primed PCR reaction mixture in a buffer containing $10 \mathrm{~mm}$ Tris- $\mathrm{HCl}|\mathrm{pH} 8.3|$, $600 \mu \mathrm{M}$ each dNTP, $5 \mu \mathrm{M}$ trimethyl ammonium chloride (Sigma), and $4.0 \mathrm{~mm} \mathrm{MgCl}_{2}$ in a $50-\mu$ l reaction mixture (Rappolee et al. 1988a). The mixture was overlaid with $100 \mu \mathrm{l}$ of mineral oil and amplified for 60 cycles on a Perkin-Elmer Cetus Thermocycler programmable heating block. The PCR fragments were separated on a $4 \%$ agarose $3 \%$ GTG $/ 1 \%$ Seakem, FMC Corp.) gel and visualized by ethidium bromide staining. Gels were photographed with a Polaroid MP-4, and negative images were reversed. Fragments were verified by size, restriction enzyme mapping, sequence analysis, and Southern blot analysis as described previously (Brenner et al. 1989; Telford et al. 1990|. For restriction enzyme analysis, the fragments were precipitated with ammonium acetate directly from the PCR mixture, washed twice with $70 \%$ ethanol, and digested according to the restriction enzyme manufacturer's instructions.

For quantification of mRNA, PCR was performed with endlabeled oligonucleotides: $5 \mu \mathrm{l}$ of the $3^{\prime}$ and $5^{\prime}$ primers at 50 pmole $/ \mu \mathrm{l}$ was mixed with $5 \mu \mathrm{l}$ of $\mathrm{T} 4$ polynucleotide kinase $(10,000 \mathrm{U} / \mathrm{ml}$; New England BioLabs $\}$ and $250 \mu \mathrm{Ci}$ of $\left[\gamma^{-32} \mathrm{P}\right] \mathrm{ATP}$ and incubated overnight at ambient temperature (Chelly et al. 1988). Unincorporated radionucleotides were removed, and the labeled primers were used in 24 reactions. Fourfold dilutions were mixed and amplified as described for 40 cycles (Fig. 7 a).
Products were separated by $6 \%$ polyacrylamide gel electrophoresis and autoradiographed, the bands were excised, and radioactivity was determined by liquid scintillation spectrometry.

\section{Immunofluorescence and nuclear staining}

For immunocytochemistry, blastocysts were either fixed in solution without centrifugation or centrifuged onto poly-L-lysinecoated coverslips in a Shandon cytocentrifuge at $900 \mathrm{rpm}$ for 30 min and fixed in $2 \%$ paraformaldehyde ( $\mathrm{pH} 7.2)$. The blastocysts were stained with rabbit polyclonal anti-rat IGF-II antibody (diluted at $1: 200$ ) with or without $0.5 \mu \mathrm{g}$ of rat IGF-II to absorb the anti-IGF-II antibody. The primary antibody was followed by biotinylated anti-rabbit IgG and then with streptavidin-Texas Red as described previously (Rappolee et al. 1988a). Embryos fixed and stained in solution were viewed in rectangular microcapillary tubes (Vitro Dynamics). Rhodamine-phalloidin was used to visualize actin as a control protein. All photography was performed with a Zeiss Photomicroscope III and water immersion $25 \times$ or $63 \times$ phase Plan-Neofluor lenses, and Tri-X film was exposed and developed under similar lighting conditions.

To determine the response of embryos, IGF-I (Amgen), IGF-II (Eli Lilly), and [Leu ${ }^{27}$ ]IGF-II were serially diluted in 100- $\mu$ l volumes and added at appropriate concentrations with 20 two-cell embryos in 20- $\mu 1$ droplets under oil and cultured for 3 days; blastocysts were then fixed onto glass coverslips and stained.

For staining of nuclei, embryos were fixed in solution by $3: 1$ (vol/vol) ethanol/glacial acetic acid, dried onto coverslips, and incubated in $1 \mu \mathrm{g} / \mathrm{ml}$ of Hoechst 33258 in water for $5 \mathrm{~min}$ and destained overnight (Handyside and Hunter 1984). Nuclei were photographed as described above.

\section{Antisense oligonucleotide experiments}

To determine the incorporation of oligonucleotides into embryos, the sense and antisense oligonucleotides were end-labeled as described above for RT-PCR. Compacted eight-cell embryos were incubated with $30 \mu \mathrm{M}$ labeled oligonucleotides for 24 $\mathrm{hr}$ in $20-\mu \mathrm{l}$ drops of TE. Embryos were then washed six times and incubated in TE medium without labeled oligonucleotides for $6 \mathrm{hr}$, washed through 6 more drops of unlabeled medium, fixed onto microscope slides, coated with photographic emulsion, and exposed and developed. Control embryos were incubated with $30 \mu \mathrm{M}$ unlabeled oligonucleotides for $24 \mathrm{hr}$, washed through medium with labeled oligonucleotides for $1 \mathrm{~min}$, and treated as described above. In some experiments, blastocysts were washed and incorporation of labeled oligonucleotides per 20 embryos was determined by liquid scintillation spectrometry. Incorporation per blastocyst (counts per minute) was calculated by dividing total counts per minute by the number of blastocysts. The number of oligonucleotide molecules per blastocyst was then determined from the specific activity of the labeled oligonucleotides (Holt et al. 1988).

For determination of the effects of oligonucleotides on growth, two-cell embryos were cultured in $30 \mu \mathrm{M}$ sense or antisense IGF-II oligonucleotides in 20- $\mu$ l drops of TE for $72 \mathrm{hr}$ with or without $10 \mathrm{nM}$ recombinant IGF-II. The percentage of embryos reaching the blastocyst stage was determined by phase microscopy at 24-hr intervals. The effects on endogenous IGF-II were studied by centrifuging the embryos onto coverslips after $72 \mathrm{hr}$ and then staining for immunofluorescence with anti-IGFII antibodies as described above. For determination of effects on specific mRNAs from the cultured embryos, RNA was isolated and IGF-II and GAPDH transcripts were assayed by RT-PCR and quantified as described above. Effects on cell number were determined by fixing embryos onto coverslips and counting nu- 
clei after Hoechst staining as described above. All experiments were performed at least twice. All values are expressed as mean \pm S.D. for three replicates.

\section{Oligonucleotides}

The designs of oligonucleotides used in this study showing sequence position by amino acid residue or nucleotide are given below.

Initiation codon oligonucleotides IGF-II (mouse; amino acid -24) antisense, 5'-TGGGGATCCCAGTGGGGTAC-3'; IGF-II (mouse; amino acid -24) sense, 5'-GTACCCCACTGGGATCCCCA-3'.

PCR primers IGF-II (mouse; amino acid 3) 5' primer, 5'-GGCCCCGGAGAGACTCTGTGC-3'; IGF-II (mouse; amino acid 87) 3' primer, 5'-GCCCACGGGGTATCTGGGGAA-3'; IGF-I (rat; amino acid 1) $5^{\prime}$ primer, 5'-GGACCAGAGACCCTTTGCGGGG-3'; IGF-I (rat; amino acid 70) 3' primer, 5'-GGCTGCTTTTGTAGGCTTCAGTGG- ${ }^{\prime}$; insulin (mouse; nucleotide 1144) 5' primer, 5'-ATGCGCTTCCTGCCCCTGCTGGC-3'; insulin (mouse; nucleotide 1931) 3' primer, 5'-CTGGTAGAGGGAGCAGATGCTGGT-3'; IGF-II receptor (rat; nucleotide 5048) 5' primer, 5'-TGTACACTCTTCTTCTCCTGGCA-3'; IGF-II receptor (rat; nucleotide 5233) 3' primer, 5'-AGAGATGTTGATGTAGAAGACAGG-3'; IGF-I receptor (human; nucleotide 3769) 5' primer, 5'-ACTGACCTCATGCGCATGTGCTGG-3'; IGF-I receptor (human; nucleotide 4113) 3' primer, 5'-CTCGTTCTTGCGGCCCCCGTTCAT-3'; insulin receptor (human; nucleotide 3934) $5^{\prime}$ primer, $5^{\prime}$-ACTGACCTCATGCGCATGTGCTGG-3'; insulin receptor (human; nucleotide 4252) 3' primer, 5'-GCCCGTTTTTCTTGCCTCCGTTCAT-3'; GAPDH (rat/human; nucleotide 838) 5' primer, 5'-TGACATCAAGAAGGTGAAG-3'; GAPDH (rat/human; nucleotide 1087) 3' primer, 5'-TCCTTGGAGGCCATGTAGGCC-3'. The sources for the sequences and sequence positions used are as follows: mouse IGF-II (Stempien et al. 1986); rat IGF-I (Bell et al. 1986); mouse insulin (Wentworth et al. 1986); rat IGF-II receptor (unpublished sequence from D.O. Morgan, UCSF); human IGF-I receptor and insulin receptor (Ebina et al. 1985; Ullrich et al. 1985, 1986). Actin oligonucleotides have been published previously (Rappolee et al. 1988a).

\section{Acknowledgments}

We thank P. Nissley, R. Rosenfeld, and Eli Lilly Corp. for their generosity in providing reagents for this study, D.O. Morgan for sharing the unpublished sequence of the rat IGF-II receptor, and M.L. Flannery for technical assistance. We thank R. Lyman and L. Hartanto for typing the manuscript and M. McKenney for editing it. This work was supported by National Institutes of Health grants HD23529 (Z.W.), HD2351] (G.A.S.), HD26732 (Z.W., R.A.P.), and HD2365I (R.A.P.), by National Research Service Award 5 T32 ES07102 from the National Institute of Environmental Health Sciences, and by contract DE-AC03-76SF01012 from the Office of Health and Environmental Research, U.S. Department of Energy.

The publication costs of this article were defrayed in part by payment of page charges. This article must therefore be hereby marked "advertisement" in accordance with 18 USC section 1734 solely to indicate this fact.

\section{References}

Barlow, D.P., R. Stoger, B.G. Hermann, K. Saito, and N. Schweifer. 1991. The mouse insulin-like growth factor type-2 re- ceptor is imprinted and closely linked to the Tme locus. Nature 349: 84-87.

Barton, S.C., M.L. Norris, and M.S.H. Surani. 1987. Nuclear transplantation in fertilized and parthenogenetically activated eggs. In Mammalian development: A practical approach (ed. M. Monk), pp. 235-253. IRL Press, New York.

Beck, F., N.J. Samani, J.D. Penschow, B. Thorley, G.W. Tregear, and I.P. Coghlan. 1987. Histochemical localization of IGF-I and -II mRNA in the developing rat embryo. Development 101: 175-184.

Becker, D., C.B. Meier, and M. Herlyn. 1989. Proliferation of human malignant melanomas is inhibited by antisense oligodeoxynucleotides targeted against basic fibroblast growth factor. EMBO /. 8: 3685-3691.

Bell, G.I., M.M. Stempien, N.M. Fong, and L.B. Rall. 1986. Sequences of liver cDNAs encoding two different mouse insulin-like growth factor I precursors. Nucleic Acids Res. 14: 7873-7882.

Beukers, M.W., Y. Oh, H. Zhang, N. Ling, and R.G. Rosenfeld. 1991. [Leu ${ }^{27}$ ] insulin-like growth factor II is highly selective for the type-II IGF receptor in binding, cross-linking and thymidine incorporation experiments. Endocrinology 128: 1201-1203.

Bevilacqua, A., R.P. Erickson, and V. Hieber. 1988. Antisense RNA inhibits endogenous gene expression in mouse preimplantation embryos: Lack of double-stranded RNA "melting" activity. Proc. Natl. Acad. Sci. 85: 831-835.

Biggers, J.D., J.E. Bell, and D.J. Benos. 1988. Mammalian blastocyst: Transport functions in a developing epithelium. Am. J. Physiol. 255: C419-C432.

Brenner, C.A., R.R. Adler, D.A. Rappolee, R.A. Pedersen, and Z. Werb. 1989. Genes for extracellular-matrix-degrading metalloproteinases and their inhibitor, TIMP, are expressed during early mammalian development. Genes \& Dev. 3: 848-859.

Brice, A.L., J.E. Cheetham, V.N. Bolton, N.C.W. Hill, and P.N. Schofield. 1989. Temporal changes in the expression of the insulin-like growth factor II gene associated with tissue maturation in the human fetus. Development 106: 543-554.

Buehr, M. and A. McLaren. 1974. Size regulation in chimaeric mouse embryos. I. Embryol. Exp. Morphol. 31: 229-234.

Chatot, C.L., C.A. Ziomek, B.D. Bavister, J.L. Lewis, and I. Torres. 1989. An improved culture medium supports development of random-bred 1-cell mouse embryos in vitro. $/$. Reprod. Fert. 86: 679-688.

Chelly, J., J.C. Kaplan, P. Maire, S. Gautron, and A. Kahn. 1988. Transcription of the dystrophin gene in human muscle and non-muscle tissue. Nature 333: 858-860.

Chirgwin, J.M., A.E. Przybyla, R.J. MacDonald, and W.J. Rutter. 1979. Isolation of biologically active ribonucleic acid from sources enriched in ribonuclease. Biochemistry 18: 52945299.

Clairmont, K.B. and M.P. Czech. 1989. Chicken and Xenopus mannose-6-phosphate receptors fail to bind insulin-like growth factor II. J. Biol. Chem. 264: 16390-16392.

Conquet, F. and P. Brulet. 1990. Developmental expression of myeloid leukemia inhibitory factor gene in preimplantation blastocysts and in extraembryonic tissue of mouse embryos. Mol. Cell. Biol. 10: 3801-3805.

Cruz, Y.P. and R.A. Pedersen. 1991. Origin of embryonic and extraembryonic cell lineages in mammalian embryos. In $A n$ imal applications of research in mammalian development (ed. R.A. Pedersen, A. McLaren, and N. First), pp. 147-204. Cold Spring Harbor Laboratory Press, Cold Spring Harbor, New York.

Czech, M.P. 1989. Signal transmission by the insulin-like growth factors. Cell 59: 235-238. 
DeChiara, T.M., A. Efstratiadis, and E.J. Robertson. 1990. A growth-deficiency phenotype in heterozygous mice carrying an insulin-like growth factor II gene disrupted by targeting. Nature 345: 78-80.

DeChiara, T.M., E.J. Robertson, and A. Efstratiadis. 1991. Parental imprinting of the mouse insulin-like growth factor II gene. Cell 64: 849-859.

Deuel, T.F. 1987. Polypeptide growth factors: Roles in normal and abnormal cell growth. Annu. Rev. Cell. Biol. 3: 443-492.

Dinarello, C.A. 1989. Interleukin-1 and its biologically related cytokines. Adv. Immunol. 44: 153-205.

Ebina, Y., L. Ellis, K. Jarnagin, M. Edery, L. Graf, E. Clauser, J. Ou, F. Masiarz, Y.W. Kan, I.D. Goldfine, R.A. Roth, and W.J. Rutter. 1985. The human insulin receptor cDNA: The structural basis for hormone-activated transmembrane signalling. Cell 40: 747-758.

Flach, G., M.H. Johnson, P.R. Braude, R.A.S. Taylor, and V.N. Bolton. 1982. The transition from maternal to embryonic control in the two-cell mouse embryo. EMBO I. 1: 681-686.

Frunzio, R., L. Chiariotti, A.L. Brown, D.E. Graham, M.M. Rechler, and C.B. Bruni. 1986. Structure and expression of the rat insulin-like growth factor II (rIGF-II) gene. rIGF-II RNAs are transcribed from two promoters. I. Biol. Chem. 261: 17138-17149.

Gardner, A. and P. Kaye. 1991. Insulin increases cell numbers and morphological development in mouse preimplantation embryos in vitro. Reprod. Fert. Devel. 3: 79-92.

Graham, D.E., M.M. Rechler, A.L. Brown, R. Frunzio, J.A. Romanus, C.B. Bruni, H.J. Whitfield, S.P. Nissley, S. Seelig, and S. Berry. 1986. Coordinate developmental regulation of high and low molecular weight mRNAs for rat insulin-like growth factor II. Proc. Natl. Acad. Sci. 83: 4519-4523.

Grant, S.G. and V.M. Chapman. 1988. Mechanisms of X-chromosome regulation. Annu. Rev. Genet. 22: 199-233.

Hahnel, A.C., D.A. Rappolee, J.L. Millan, T. Manes, C.A. Ziomek, N.G. Theodosiou, Z. Werb, R.A. Pedersen, and G.A. Schultz. 1990. Two alkaline phosphatase genes are expressed during early development in the mouse embryo. Development 110: 555-564.

Haig, D. and C. Graham. 1991. Genomic imprinting and the strange case of the insulin-like growth factor receptor. Cell 64: 1045-1046.

Haig, D. and M. Westoby. 1989. Parent-specific gene expression and the triploid endosperm. Am. Nat. 134: 147-155.

Han, V.K.M., E.S. Hunter III, R.M. Pratt, J.G. Zendegui, and D.C. Lee. 1987a. Expression of rat transforming growth factor $\alpha$ mRNA during development occurs predominantly in maternal decidua. Mol. Cell. Biol. 7: 2335-2343.

Han, V.K.M., A.J. D'Ercole, and P.K. Lund. 1987b. Cellular localization of somatomedin (insulin-like growth factor) messenger RNA in the human fetus. Science 236: 193-197.

Handyside, A.H. and S. Hunter. 1984. A rapid procedure for visualising the inner cell mass and trophectoderm nuclei of mouse blastocysts in situ using polynucleotide-specific fluorochromes. J. Exp. Zool. 231: 429-434.

Harvey, M.B. and P.L. Kaye. 1988. Insulin stimulates protein synthesis in compacted mouse embryos. Endocrinology 122: $1182-1184$.

- 1989. Insulin and IGF-I are anabolic and mitogenic in preimplantation mouse embryos. Cell Differ. Dev. 27: S31.

-1990. Insulin increases the cell number of the inner cell mass and stimulates morphological development of mouse blastocysts in vitro. Development 110: 963-967.

- 1991. Mouse blastocysts respond metabolically to shortterm stimulation by insulin and IGF-I through the insulin receptor. Mol. Reprod. Dev. 29: 253-258.
Heath, J.K. and W.-K. Shi. 1986. Developmentally regulated expression of insulin-like growth factors by differentiated murine teratocarcinomas and extraembryonic mesoderm. I. Embryol. Exp. Morphol. 95: 193-212.

Hogan, B., F. Costantini, and E. Lacy. 1986. Manipulating the mouse embryo: A laboratory manual. Cold Spring Harbor Laboratory, Cold Spring Harbor, New York.

Holt, J.T., R.L. Redner, and A.W. Nienhuis. 1988. An oligomer complementary to c-myc mRNA inhibits proliferation of HL-60 promyelocytic cells and induces differentiation. Mol. Cell. Biol. 8: 963-973.

Kelly, S.J. 1977. Studies of the developmental potential of 4- and eight-cell stage mouse blastomeres. I. Exp. Zool. 200: 365376.

Kiess, W., J.F. Haskell, L. Lee, L.A. Greenstein, B.E. Miller, A.L. Aarons, M.M. Rechler, and S.P. Nissley. 1987. An antibody that blocks insulin-like growth factor (IGF) binding to the type II IGF receptor is neither an agonist nor an inhibitor of IGF-stimulated biologic responses in 26 myoblasts. $J$. Biol. Chem. 262: 12745-12751.

Ko, Y., C.Y. Lee, T.L. Ott, M.A. Davis, R.C.M. Simmen, F.W. Bazer, and F.A. Simmen. 1991. Insulin-like growth factors in sheep uterine fluids: Concentrations and relationship to ovine trophoblast protein-l production during early pregnancy. Biol. Reprod. 45: 135-142.

Lee, J.E., J. Pintar, and A. Efstratiadis. 1990. Pattern of the insulin-like-growth-factor-II gene expression during early mouse embryogenesis. Development 110: 151-159.

Lewis, N.E. and J. Rossant. 1982. Mechanism of size regulation in mouse embryo aggregates. I. Embryol. Exp. Morphol. 72: $169-181$.

Liu, L., S. Greenberg, S.M. Russell, and C.S. Nicoll. 1989. Effects of insulin-like growth factors I and II on growth and differentiation of transplanted rat embryos and fetal tissues. Endocrinology 124: 3077-3082.

Lock, L.F., N. Takagi, and G.R. Martin. 1987. Methylation of the Hprt gene on the inactive $\mathrm{X}$ occurs after chromosome inactivation. Cell 48: 39-46.

MacDonald, R.G., S.R. Pfeffer, L. Coussens, M.A. Tepper, C.M. Brocklebank, J.E. Mole, J.K. Anderson, E. Chen, M.P. Czech, and A. Ullrich. 1988. A single receptor binds both insulinlike growth factor II and mannose 6-phosphate. Science 239: 1134-1137.

Marcus-Sekura, C.J. 1988. Techniques for using antisense oligodeoxyribonucleotides to study gene expression. Anal. Biochem. 172: 289-295.

Mattson, B.A., I.Y. Rosenblum, R.M. Smith, and S. Heyner. 1988. Autoradiographic evidence for insulin and insulin-like growth factor binding to early mouse embryos. Diabetes 37: $585-589$.

Murray, R., F. Lee, and C.P. Chiu. 1990. The genes for leukemia inhibitory factor and interleukin- 6 are expressed in mouse blastocysts prior to the onset of hemopoiesis. Mol. Cell. Biol. 10: 4953-4956.

Nishimoto, I. and I. Kojima. 1989. Calcium signalling system triggered by insulin-like growth factor II. News Physiol. Sci. 4: 94-97.

Ohlsson, R., L. Holmgren, A. Glaser, A. Szpecht, and S. PfeiferOhlsson. 1989a. Insulin-like growth factor 2 and short-range stimulatory loops in control of human placental growth. EMBO /. 8: 1993-1999.

Ohlsson, R., E. Larsson, O. Nilsson, T. Wahlstrom, and P. Sundstrom. 1989b. Blastocyst implantation precedes induction of insulin-like growth factor II gene expression in human trophoblasts. Development 106: 555-559.

Okamoto, T., T. Katada, Y. Murayama, M. Ui, E. Ogata, and I. 
Nishimoto. 1990a. A simple structure encodes $G$ proteinactivating function of the IGF-II/mannose-6-phosphate receptor. Cell 62: 709-717.

Okamoto, T., I. Nishimoto, Y. Murayama, Y. Ohkuni, and E. Ogata. 1990b. Insulin-like growth factor-II/mannose-6-phosphate receptor is incapable of activating GTP-binding proteins in response to mannose-6-phosphate, but capable in response to insulin-like growth factor-II. Biochem. Biophys. Res. Comm. 168: 1201-1210.

Osborne, C.K., E.B. Coronado, L.J. Kitten, C.I. Arteaga, S.A. Fuqua, K. Ramasharma, M. Marshall, and C.H. Li. 1989. Insulin-like growth factor-II (IGF-II): A potential autocrine/paracrine growth factor for human breast cancer acting via the IGF-I receptor. Mol. Endocrinol. 3: 1701-1709.

Pampfer, S., R. de Hertogh, I. Vanderheyden, B. Michiels, and M. Vercheval. 1990. Decreased inner cell mass proportion in blastocysts from diabetic rats. Diabetes 39: 471-476.

Paria, B.C. and S.K. Dey. 1990. Preimplantation embryo development in vitro: Cooperative interactions among embryos and role of growth factors. Proc. Natl. Acad. Sci. 87: 47564760.

Pedersen, R.A. 1986. Potency, lineage, and allocation in preimplantation mouse embryo. In Experimental approaches to mammalian embryonic development (ed. J. Rossant and R.A. Pedersen), pp. 3-33. Cambridge University Press, Cambridge, England.

Pedersen, R.A., K.S. Sturm, D.A. Rappolee, and Z. Werb. 1992. Effects of imprinting or early development of mouse embryos. In Proceedings of the Serono symposium on preimplantation embryo development. (In press.)

Pikó, L. and K.B. Clegg. 1982. Quantitative changes in total RNA, total poly(A), and ribosomes in early mouse embryos. Dev. Biol. 89: 362-378.

Rappolee, D.A., C.A. Brenner, R. Schultz, D. Mark, and Z. Werb. 1988a. Developmental expression of PDGF, TGF- $\alpha$, and TGF- $\beta$ genes in preimplantation mouse embryos. Science 241: $1823-1825$.

Rappolee, D.A., D. Mark, M.J. Banda, and Z. Werb. 1988b. Wound macrophages express TGF- $\alpha$ and other growth factors in vivo: Analysis by mRNA phenotyping. Science 241: 708-712.

Rappolee, D.A., A. Wang, D. Mark, and Z. Werb. 1989. Novel method for studying mRNA phenotypes in single or small numbers of cells. I. Cell. Biochem. 39: 1-11.

Rappolee, D.A., K.S. Sturm, G.A. Schultz, R.A. Pedersen, and Z. Werb. 1990. The expression of growth factor ligands and receptors in preimplantation mouse embryos. In Early embryo development and paracrine relationships (ed. S. Heyner and L. Wiley), pp. 11-25. Wiley-Liss, New York.

Roth, R.A. 1988. Structure of the receptor for insulin-like growth factor II: The puzzle amplified. Science 239: 12691271.

Rotwein, P., K.M. Pollock, M. Watson, and J.D. Milbrandt. 1987. Insulin-like growth factor gene expression during rat embryonic development. Endocrinology 121: 2141-2144.

Sakano, K., T. Enjoh, F. Numata, H. Fugiwara, Y. Marumoto, N. Higashihashi, Y. Sato, J.F. Perdue, and Y. Fujita-Yamaguchi. 1991. The design, expression, and characterization of human insulin-like growth factor II (IGF-II) mutants specific for either the IGF-II/cation-independent mannose-6-phosphate receptor or IGF-I receptor. I. Biol. Chem. 266: 20626-20635.

Sara, V.R. and K. Hall. 1990. Insulin-like growth factors and their binding proteins. Physiol. Rev. 70: 591-614.

Schultz, G.A. 1986. Utilization of genetic information in the preimplantation mouse embryo. In Experimental approaches to mammalian embryonic development (ed. J.
Rossant and R.A. Pedersen), pp. 239-265. Cambridge University Press, Cambridge, England.

Senior, P.V., S. Byrne, W.J. Brammar, and F. Beck. 1990. Expression of the IGF-II/mannose-6-phosphate receptor mRNA and protein in the developing rat. Development 109: 67-73.

Smith, E.P., T.W. Sadler, and A.J. D'Ercole. 1987. Somatomedins/insulin-like growth factors, their receptors and binding proteins are present during mouse embryogenesis. Development 101: 73-82.

Spindle, A. 1980. An improved culture medium for mouse blastocysts. In Vitro 16: 669-674.

- 1990. In vitro development of one-cell embryos from outbred mice: Influence of culture medium composition. In Vitro Cell. Dev. Biol. 25: 151-156.

Stein, C.A. and J.S. Cohen. 1988. Oligodeoxynucleotides as inhibitors of gene expression: A review. Cancer Res. 48: 26592668.

Stempien, M.M., N.M. Fong, L.B. Rall, and G.I. Bell. 1986. Sequence of a placental cDNA encoding the mouse insulinlike growth factor II precursor. DNA 5: 357-361.

Stylianopoulou, F., J. Herbert, M.B. Soares, and A. Efstratiadis. 1986. Expression of the insulin-like growth factor II gene in the choroid plexus and the leptomeninges of the adult rat central nervous system. Proc. Natl. Acad. Sci. 85: 141-145.

Stylianopoulou, F., A. Efstratiadis, J. Herbert, and J. Pintar. 1988. Pattern of the insulin-like growth factor II gene expression during rat embryogenesis. Development 103: 497-506.

Telford, N.A., A. Hogan, C.R. Franz, and G.A. Schultz. 1990. Expression of genes for insulin and insulin-like growth factors and receptors in early postimplantation mouse embryos and embryonal carcinoma cells. Mol. Reprod. Devel. 27: 8192.

Ullrich, A., J.R. Bell, E.Y. Chen, R. Herrera, L.M. Petruzzelli, T.J. Dull, A. Gray, L. Coussens, Y.-C. Liao, M. Tsubokawa, A. Mason, P.H. Seeburg, C. Grunfeld, O.M. Rosen, and J. Ramachandran. 1985. Human insulin receptor and its relationship to the tyrosine kinase family of oncogenes. Nature 313: 756-761.

Ullrich, A., A. Gray, A.W. Tam, T. Yang-Feng, M. Tsubokawa, C. Collins, W. Henzel, T. Le Bon, S. Kathuria, E. Chen, S. Jacobs, U. Francke, J. Ramachandran, and Y. Fujita-Yamaguchi. 1986. Insulin-like growth factor I receptor primary structure: Comparison with insulin receptor suggests structural determinants that define functional specificity. $E M B O$ I. 5: 2503-2512.

Wentworth, B.M., I.M. Schaefer, L. Villa-Komaroff, and J.M. Chirgwin. 1986. Characterization of two nonallelic genes encoding mouse preproinsulin. J. Mol. Evol. 23: 305-312.

Zeller, R., L. Jackson-Grusby, and P. Leder. 1989. The limb deformity gene is required for apical ectodermal ridge differentiation and anteroposterior limb pattern formation. Genes \& Dev. 3: 1481-1492. 


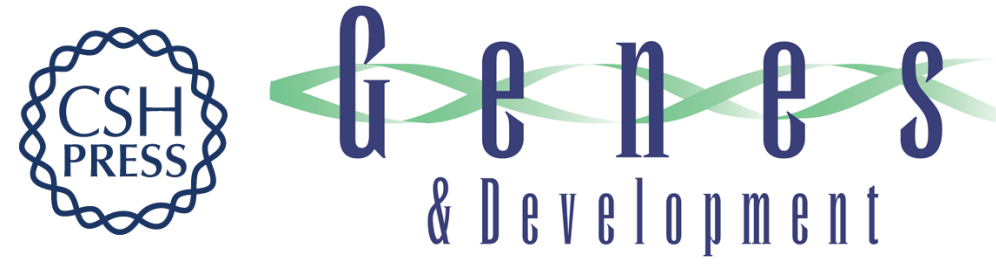

\section{Insulin-like growth factor II acts through an endogenous growth pathway regulated by imprinting in early mouse embryos.}

D A Rappolee, K S Sturm, O Behrendtsen, et al.

Genes Dev. 1992, 6:

Access the most recent version at doi:10.1101/gad.6.6.939

References This article cites 78 articles, 31 of which can be accessed free at:

http://genesdev.cshlp.org/content/6/6/939.full.html\#ref-list-1

License

Email Alerting

Service

Receive free email alerts when new articles cite this article - sign up in the box at the top right corner of the article or click here.

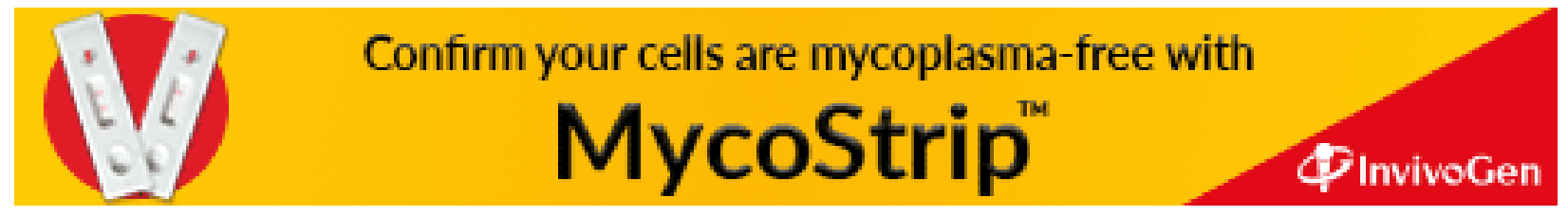

